\title{
Effect of Using Fins on Cell Temperature at Air-Based PVT
}

\section{Ahmet Numan ÖZAKIN ${ }^{1}$, Ferhat KAYA ${ }^{2 *}$}

\begin{abstract}
ABRACT: In this study, the effect of addition of fins in air-based PVT system on cell temperature investigated. Experimental tests were performed with frequent and sparse fins configurations and also empty(non-finned) state. Also, thermal camera images of cells were investigated and compared to images obtained by Fluent Ansys. Cell temperatures for all status of both polycrystal and monocrystal panel decreased between $8-20{ }^{\circ} \mathrm{C}$. Panel surface was observed to have a uniform temperature distribution. Finally, temperature distribution images obtained with ANSYS Fluent were found to be quite compatible with thermal camera images.
\end{abstract}

Keywords: air-based PVT system, copper fins, cell temperature, Ansys Fluent, thermal camera

\footnotetext{
${ }^{1}$ Ahmet Numan ÖZAKIN (Orcid ID: 0000-0002-2083-8703), Atatürk University, Faculty of Engineering, Department of Mechanical Engineering, Erzurum, Turkey

${ }^{2}$ Ferhat KAYA (Orcid ID: 0000-0002-8165-8300), Igdir University, Faculty of Engineering, Department of Mechanical Engineering, Igdir, Turkey

*Sorumlu Yazar/Corresponding Author: Ferhat KAYA, e-mail: ferhat.kaya@igdir.edu.tr

* This work was produced from Ahmet Numan ÖZAKIN's Master's thesis.
} 


\section{INTRODUCTION}

Since solar energy is an energy source clean, inexhaustible and accessible to everyone, it has been observed there is an enormous increase in use of solar cells worldwide Solar cells convert sunlight directly into electrical energy. While PV panels convert about $10-20 \%$ of solar radiation into electrical energy, $80-90 \%$ of energy convert into thermal energy called as waste heat, which causes an increase in panel temperature. Panel surface overheats in especially hot climatic zones and summer. This, not only reduces lifetime of panel as it causes thermal stress in PV module but also reduces electrical efficiency. Each $1{ }^{\circ} \mathrm{C}$ temperature increase above ideal operating temperature of panel leads to a reduction in conversion efficiency of up to $0.65 \%$. Also, one of problems seen in PV systems is non-uniform temperature distribution on panel surface, which adversely affects panel efficiency (Tonui and Tripanagnostopoulos, 2008; Gang et al., 2011; Kumar and Rosen, 2011a; Saidur et al., 2012; Cuce et al., 2013; Dubey and Tay, 2013; Yang and Athienitis, 2014; Baloch et al., 2015; Yang et al., 2015; Bahaidarah et al., 2016; Al-Waeli et al., 2017; Chandel and Agarwal, 2017; Shukla et al., 2017; Omer and Zala, 2018; Fayaz et al., 2019; Bayrak et al., 2017; Lamnatou and Chemisana, 2017; Shukla et al., 2017; Kazemian et al., 2018; Özakin and Kaya, 2019).

In order to overcome these disadvantages, waste heat accumulated in panel must be removed. PVT systems are designed to increase efficiency by removing waste heat from PV panels and to use waste heat for useful purposes such as indoor heating, water heating, fruit or vegetable drying. Thereby, not only electricity is generated but also waste heat is utilized for various useful purposes In addition, a uniform temperature distribution is obtained on surface of panel thanks to cooling process applied. Compared to two separate systems required to generate heat and electricity, PVTs not only require low cost and less space but also have a lower payback time. Air, water, nanofluids, and PCMs have been used as a refrigerant in many different studies to make waste heat accumulated in panels usable ((Dubey and Tiwari, 2008; Tonui and Tripanagnostopoulos, 2008; Kumar and Rosen, 2011a; Kumar et al., 2011b; Saidur et al., 2012; Yang and Athienitis, 2014; Yang and Athienitis, 2015; Bayrak et al., 2017; Chauhan et al., 2018; Kazemian et al., 2018; Özakin and Kaya, 2019; Wu et al., 2019; Fayaz et al., 2019). Water has higher heat capacity and thermal conductivity, so water-cooled PVT systems outperform other systems. PVTs can be classified with respect to glazed or unglazed, and single or double flow. Singleflows are classified as over or under plate, while double flows are classified as same direction or opposite direction (Kumar and Rosen, 2011b; Bayrak et al., 2017). Cell temperature for an ambient temperature of $20^{\circ} \mathrm{C}$, radiation of $800 \mathrm{~W} \mathrm{~m}^{-2}$ and a wind speed of $1 \mathrm{~m} \mathrm{~s}^{-1}$ is about $45^{\circ} \mathrm{C}$. This value is called nominal operating cell temperature, where ideal electrical efficiency of panel is obtained (Kaldellis et al., 2014). In addition, conversion efficiency values are obtained by PV panel manufacturers according to standard test conditions (STC) $\left(1000 \mathrm{Wm}^{-2}\right.$ solar radiation, $25^{\circ} \mathrm{C}$ cell temperature and 1.5 air mass flow) (Kumar and Rosen, 2011a; Kumar and Rosen, 2011b; Gökmen et al., 2016; Bora et al, 2018; Venkateswari and Sreejith, 2019; Ceylan et al., 2019; Ustun et al., 2019; Ghosh et al., 2019). Solar cell temperature is can well above ideal due to seasonal and regional factors in outdoor ambiance conditions.

Recently, many studies have been carried out to decrease surface temperature of PV panel. In a study conducted in S. Arabia, it was reported that while cell temperature as a result of use of PVT decreased from $71.2{ }^{\circ} \mathrm{C}$ to $45.1{ }^{\circ} \mathrm{C}$ in June, and its decreased from $48.3{ }^{\circ} \mathrm{C}$ to $36.4{ }^{\circ} \mathrm{C}$ in December (Baloch et al., 2015). As a result of water-cooling process applied to back of panel in S. Arabia, it was reported that efficiency increased by $9 \%$, while cell temperature decreased by $20 \%$ (Bahaidarah et al., 2013). In study performed according to two different mass flow rates, thermal efficiency and electrical efficiency were observed to be $40.7 \%$ and $11.8 \%$ for monocrystal panel and $39.4 \%$ and $11.5 \%$ for 
polycrystal panel, respectively (Dubey and Tay, 2013). In Kirkuk, Iraq, when airflow rate was increased from 0.024 to $0.057 \mathrm{~m} 3 / \mathrm{s}$, respectively, thermal and electrical efficiencies of air-cooled PVT increased by $20 \%$ and $44 \%$, respectively (Omer and Zala, 2018). In a study conducted in Cyprus, it was stated that thermal efficiency of water-based PVT system was $49 \%$ and mean annual conversion efficiency increased from $2.8 \%$ to $7.7 \%$ (Kalogirou, 2001). Effect of fins use on thermal efficiency of air-cooled PVT system was investigated in Erzurum, Turkey, and it was explained that thermal efficiencies of polycrystal and monocrystal panels were 58\% and 65\% respectively (Özakin and Kaya, 2019). Thermodynamic analysis of PVT system was carried out in Mashhad, Iran using three different fluids (water, ethylene glycol (EG)/water mixture (50\% by weight) and pure ethylene glycol). It was stated that total energy and exergy efficiencies of EG/water mixture were very close to pure water, and they were much higher than pure ethylene glycol (Kazemian et al., 2018). Building-integrated photovoltaic thermal (BIPV/T) systems are used on fairly large scale since last quarter-century. It was stated that thermal efficiency of air-based BIPV/T system installed on roof in Quebec, Canada, was 20\% (Kaiser et al., 2014). In Montreal, Canada performance of single-inlet and two-inlet air-cooled BIPV/T system were examined and, it was that inferred thermal efficiency of two-inlet system was about $5 \%$ higher than single-inlet system (Yang and Athienitis, 2014; Yang and Athienitis, 2015).

There are many studies on PVT system. However, there are only a limited number of studies related to effect on cell temperature of fins used in air-cooled PVT systems. In this study, we were researched effect on cell temperature of using fins in air-cooling PVT system. Experiments were carried out according to empty, frequent and sparse fins configurations (three different configurations), and was analyzed effect on cell temperature. Furthermore, thermal camera images of the panel were investigated and compared to images obtained by Fluent Ansys program.

\section{MATERIALS AND METHODS}

\section{Experimental Setup}

Experimental setup shown in Figure 1.a consists of solar panels and measuring devices. Experiments were performed, in Erzurum, Turkey. Duct was produced, and it was placed back surface of panel. Air was circulated into duct via fan. Fins were used to extract more waste heat from the PVT system and to provide more efficient cooling. Both polycrystal and monocrystal panels were used during experiments and their technical characteristics were given in Table 1. Fins were made of copper and their physical properties were given in Table 2. S \& P axial fan to blow air into duct was used. The inlet and outlet air temperature of duct was measured using NOVUS-RHT temperature meter. Cell temperature was measured using $\mathrm{T}$ type thermocouples ( $40 \% \mathrm{Ni}, 60 \% \mathrm{Cu}$ alloy). All measuring devices were calibrated and adjusted according to required intervals. Fan air velocity was measured by using an anemometer with hot-wire Testo 885-2 thermal camera was used to obtained panel surface images. Data were recorded with NOVUS data logger.

\section{Ansys Fluent Analysis}

Heat and flow events within the cooling volume were analyzed with ANSYS Fluent program. Meshing module was created a solution network, then using the finite element method with FLUENT numerical solutions were produced and the results were shown in the figures. The outlet temperatures of the channel and fins temperatures were taken as the reference point. As shown in Figure 2, the results were converged after about 10 million mesh. We selected 11268753 as the optimal number of elements in our analysis. The digital network structure of the preferred model for the analysis is shown in Figure 3. 
a)

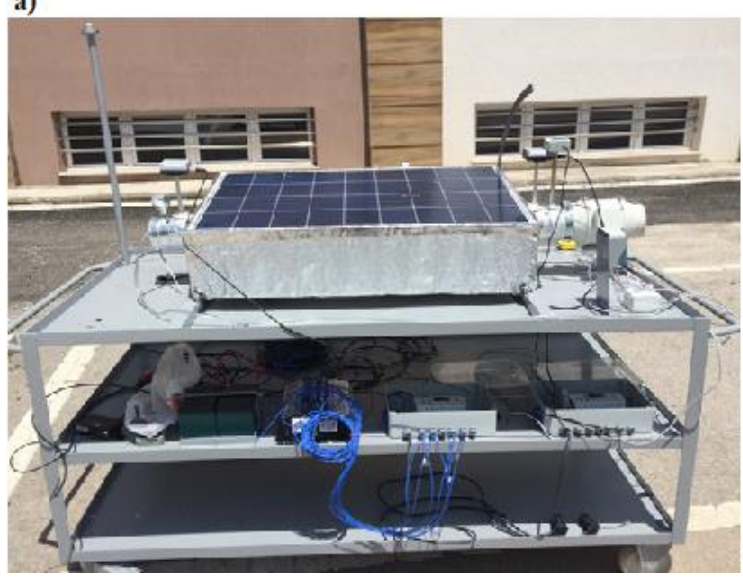

b)

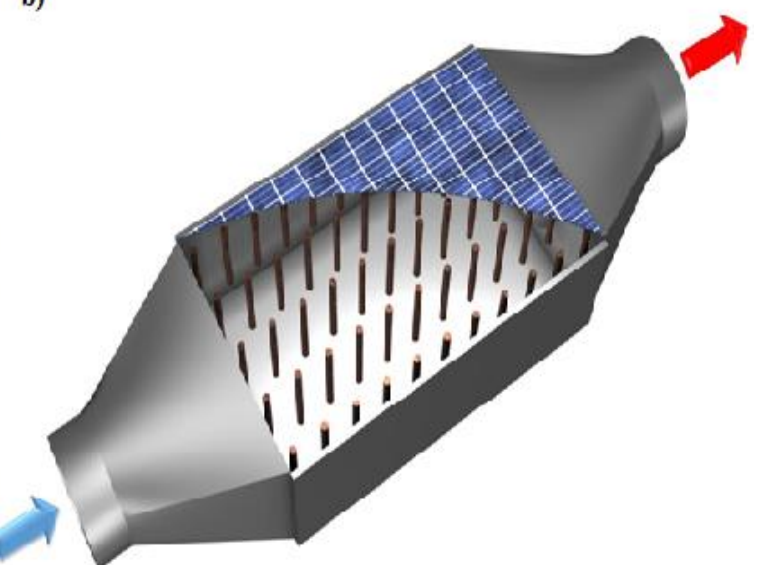

Figure 1. Experimental setup. (a) Mobile PVT system and measuring devices. b) Air duct model for frequent fins configuration).

Table 1. Technical properties of panels.

\begin{tabular}{lcccccccc}
\hline Type & Power(W) & Power Tol.(\%) & $\mathrm{I}_{\max }(\mathrm{A})$ & $\mathrm{V}_{\max }(\mathrm{V})$ & $\mathrm{I}_{\mathrm{sc}}(\mathrm{A})$ & $\mathrm{V}_{\mathrm{sc}}(\mathrm{V})$ & Weight $(\mathrm{kg})$ & Dimensions (mm) \\
\hline Poly & 100 & Max 3 & 5.23 & 19.12 & 5.6 & 22.68 & 8 & $1005 \times 668 \times 35$ \\
Mono & 100 & Max 3 & 5.17 & 19.35 & 5.53 & 22.6 & 10 & $1195 \times 545 \times 36$ \\
\hline
\end{tabular}

Table 2. Physical properties of copper cylindrical fins.

\begin{tabular}{ccccc}
\hline $\begin{array}{c}\text { Specific weight } \\
\left(\mathrm{kg} \mathrm{d}^{-1} \mathrm{~m}^{-3}\right)\end{array}$ & $\begin{array}{c}\text { Thermal cond. } \\
\left(\mathrm{W} \mathrm{m}^{-1} \mathrm{~K}^{-1}\right)\end{array}$ & $\begin{array}{c}\text { Specific heat cap. } \\
\left(\mathrm{kcal} \mathrm{kg}^{-1} \mathrm{~K}^{-1}\right)\end{array}$ & $\begin{array}{c}\text { Resistivity } \\
(\mu \Omega)\end{array}$ & $\begin{array}{c}\text { Melting point } \\
\left({ }^{\circ} \mathrm{C}\right)\end{array}$ \\
\hline 8.9 & 336 & 0.092 & 1.71 & $1065-1085$ \\
\hline
\end{tabular}

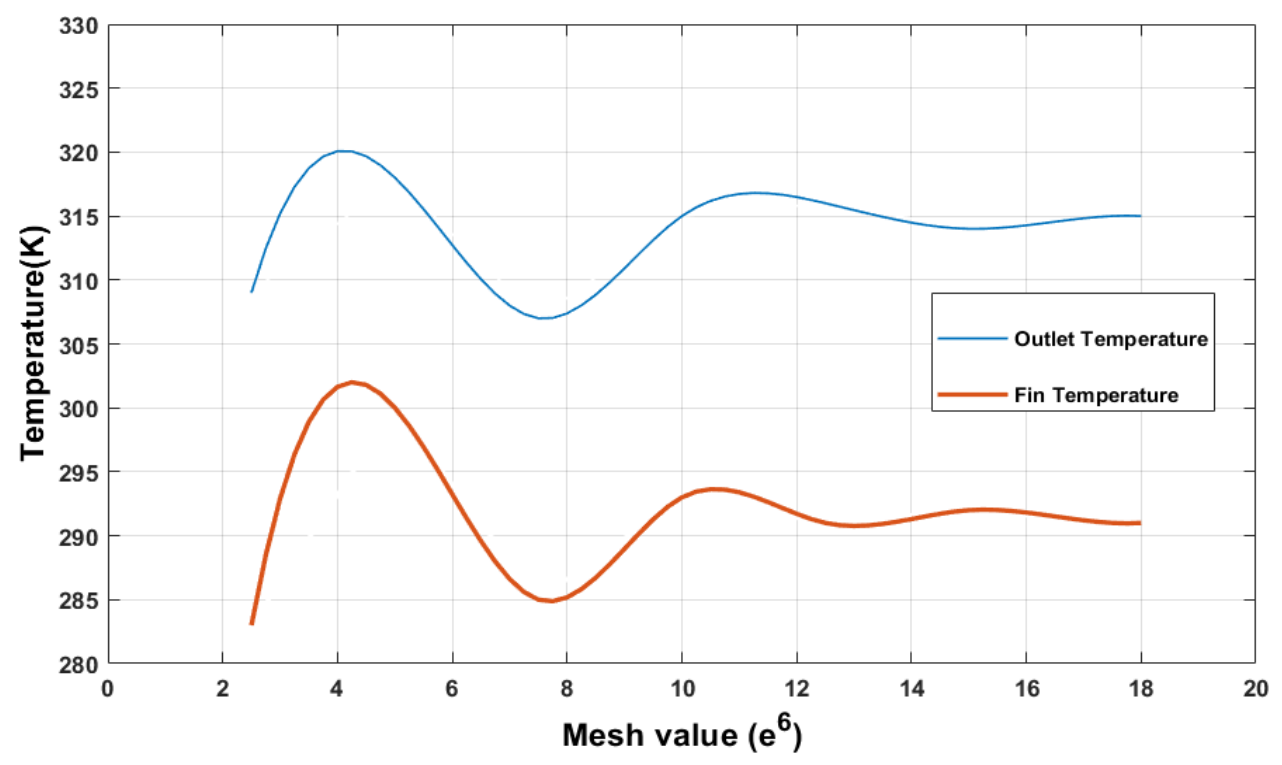

Figure 2. Mesh validation for geometry model 


\begin{tabular}{|cc|}
\hline Ahmet Numan ÖZAKIN and Ferhat KAYA & $10(1): 477-488,2020$ \\
\hline Effect of Using Fins on Cell Temperature at Air-Based PVT
\end{tabular}

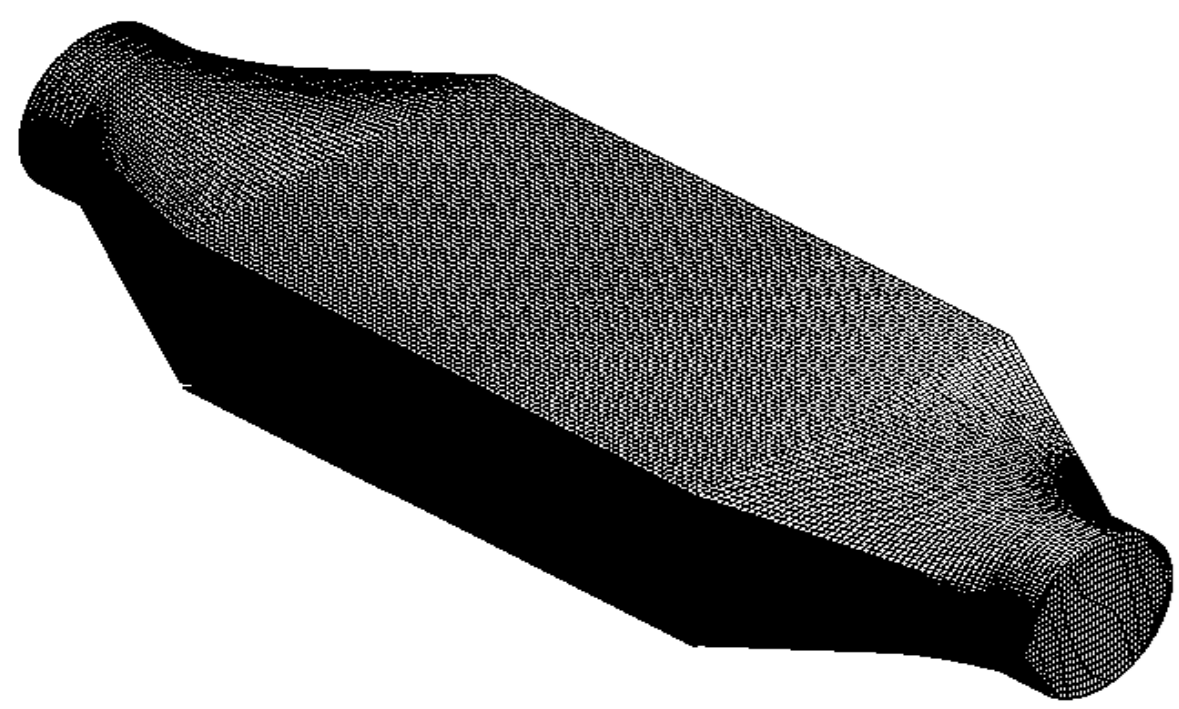

Figure.3. The mesh structure of preferred model.

Three-dimensional panel geometry analysis was performed by ANSYS Fluent program according to the boundary conditions given in Table 3 .

Table 3. Average surface temperatures and air velocities

\begin{tabular}{ccc}
\hline $\mathrm{V}\left(\mathrm{m} \mathrm{s}^{-1}\right)$ & Sparse, $\mathrm{T}\left({ }^{\circ} \mathrm{C}\right)$ & Frequent, $\mathrm{T}\left({ }^{\circ} \mathrm{C}\right)$ \\
\hline 5.1 & 44.92 & 45.15 \\
5.4 & 45.4 & 46.5 \\
5.7 & 46.4 & 47.4 \\
6 & 47.12 & 48.1 \\
\hline
\end{tabular}

\section{RESULTS AND DISCUSSION}

In air-cooling PVT, effect of frequent and sparse configurations of fins made from copper material on cell temperature was investigated. For frequent and sparse configuration, 55 and 27 fins were used respectively. Experiments were carried out according to three different configurations and results were analyzed.

\section{Temperature Difference $(\Delta \mathrm{T})$ Between Inlet and Outlet of Cooling Duct}

Experiments were carried out for non-fins, frequent and sparse fins configurations under outdoor operating conditions. Since air cooling applied into duct extracts a certain amount of heat from panel surface, temperature difference $(\Delta \mathrm{T})$ occurs between inlet and outlet of duct air. This means that a certain amount of waste heat is removed and the cell temperature is lowered by the cooling process. Figure 4 shows the variation of the $\Delta \mathrm{T}$ value with the airspeed of the fan for wingless, sparse and frequent vane conditions for both polycrystalline and monocrystalline panels. Figure 4 shows that the highest $\Delta \mathrm{T}$ value in both monocrystal and polycrystal panels belongs to the frequent fin configuration, then to sparse fins configuration and to empty state, respectively. This shows that both cooling process and addition of fins have been effective in removing waste heat from panel. Furthermore, frequent fin configuration is the 
most efficient state in removing waste heat from panel. In addition, in previous our studies, it was observed that higher electrical, thermal and exergy efficiencies were obtained for frequent fin configuration (Özakin and Kaya, 2019, Özakin and Kaya, 2020).

In monocrystal panel, when the air velocity was increased from $5.1 \mathrm{~m} \mathrm{~s}^{-1}$ to $6 \mathrm{~m} \mathrm{~s}^{-1}$, the change in $\Delta \mathrm{T}$ was observed that: is between $0.85-0.6^{\circ} \mathrm{C}$ for the empty state; is between $2.2-1.85^{\circ} \mathrm{C}$ for sparse fins condition; is between $3.35-3{ }^{\circ} \mathrm{C}$ for frequent fins. Similarly, in polycrystal panel, when the air velocity was increased from $5.1 \mathrm{~m} \mathrm{~s}^{-1}$ to $6 \mathrm{~m} \mathrm{~s}^{-1}$, the change in $\Delta \mathrm{T}$ was observed that: is between $0.75-0.65^{\circ} \mathrm{C}$ for the empty state; is between $2.15-1.85^{\circ} \mathrm{C}$ for sparse fins condition; is between $3.35-3{ }^{\circ} \mathrm{C}$ for frequent fins.
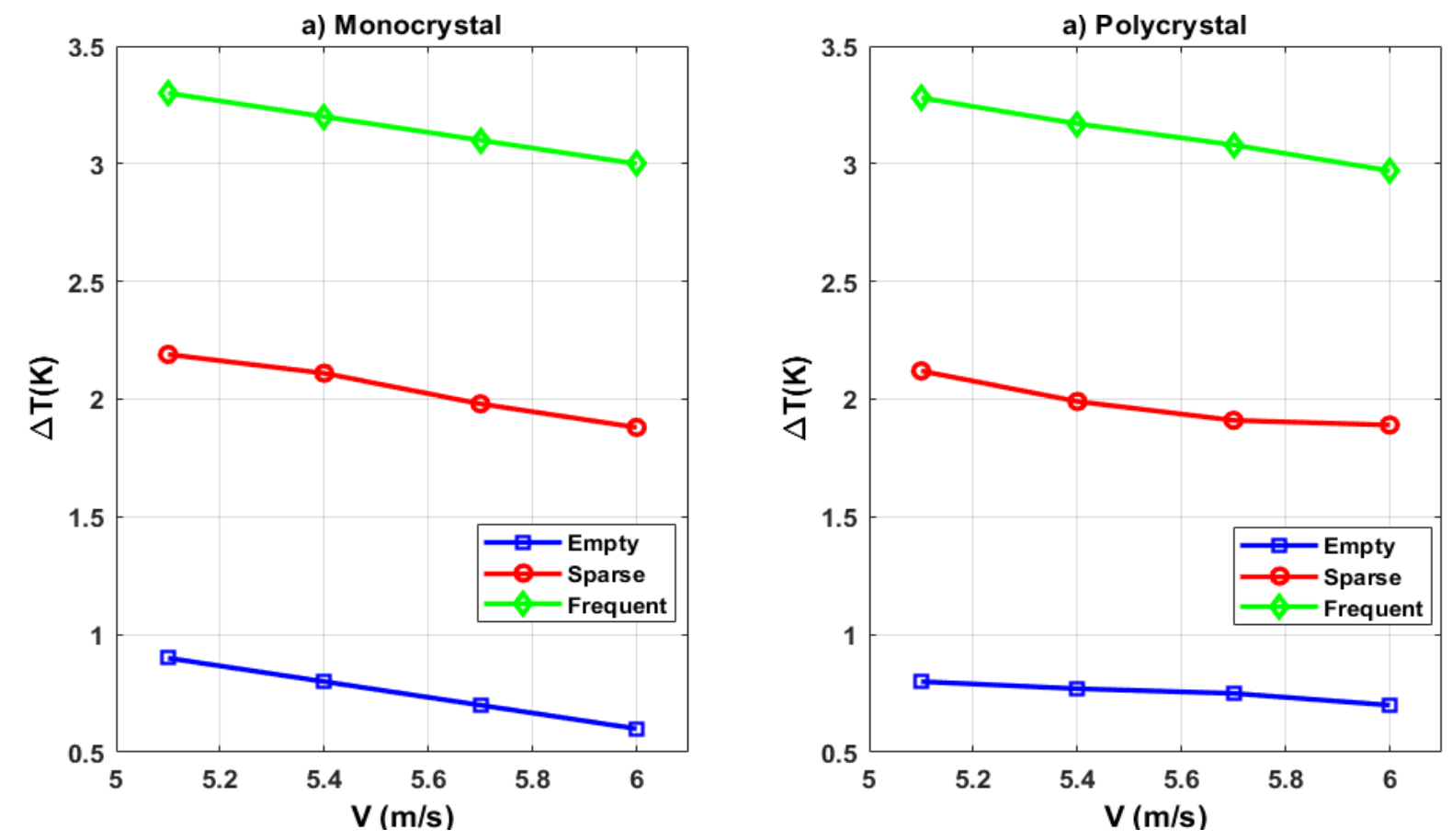

Figure 4. Variation of temperature difference between inlet and outlet of cooling channel according to air velocity.

\section{Analysis of Cell Temperature}

Experiments were carried out at 11.00-16.00 in July. It has been measured that outdoor temperature was $29-32{ }^{\circ} \mathrm{C}$, cell temperature was $63-65{ }^{\circ} \mathrm{C}$, and irradiation amount was $950-1000 \mathrm{~W} \mathrm{~m}^{-2}$ during experiments. Considering these ambient conditions, ideal operating temperature for panels is about 47 ${ }^{\circ} \mathrm{C}$. Table 4. shows temperature values of panel surface obtained for three different configurations. As seen from Table 4, It was observed cell temperatures for all three different configurations of both polycrystal and monocrystal panels were decreased between $8-20{ }^{\circ} \mathrm{C}$. In addition, cell temperatures of all three different configurations were found to be close to optimum operating temperature of cells. Kumar and Rosen (2011b) studied a double-pass air-cooled PVT system used fins and indicated that cell temperature dropped from $88^{\circ} \mathrm{C}$ to $66^{\circ} \mathrm{C}$. However, the $66^{\circ} \mathrm{C}$ temperature is well above the ideal operating temperature of the panel. As can be seen in Table 4, the surface temperature of both panels is very close to the ideal operating temperature for all configurations. 
Table 4. Surface temperature values of both panels after air cooling process.

\begin{tabular}{cccccc}
\hline & Polycrystal & & \multicolumn{3}{c}{ Monocrystal } \\
\hline Empty & Sparse & Frequent & Empty & Sparse & Frequent \\
\hline $47-49^{\circ} \mathrm{C}$ & $45-48{ }^{\circ} \mathrm{C}$ & $45-47{ }^{\circ} \mathrm{C}$ & $50-57{ }^{\circ} \mathrm{C}$ & $47-54{ }^{\circ} \mathrm{C}$ & $47-50{ }^{\circ} \mathrm{C}$ \\
\hline
\end{tabular}

Figure 5 shows thermal camera image of polycrystal panel surface for sparse and frequent configurations. As seen from thermal camera images, panel surfaces have a uniform temperature distribution.
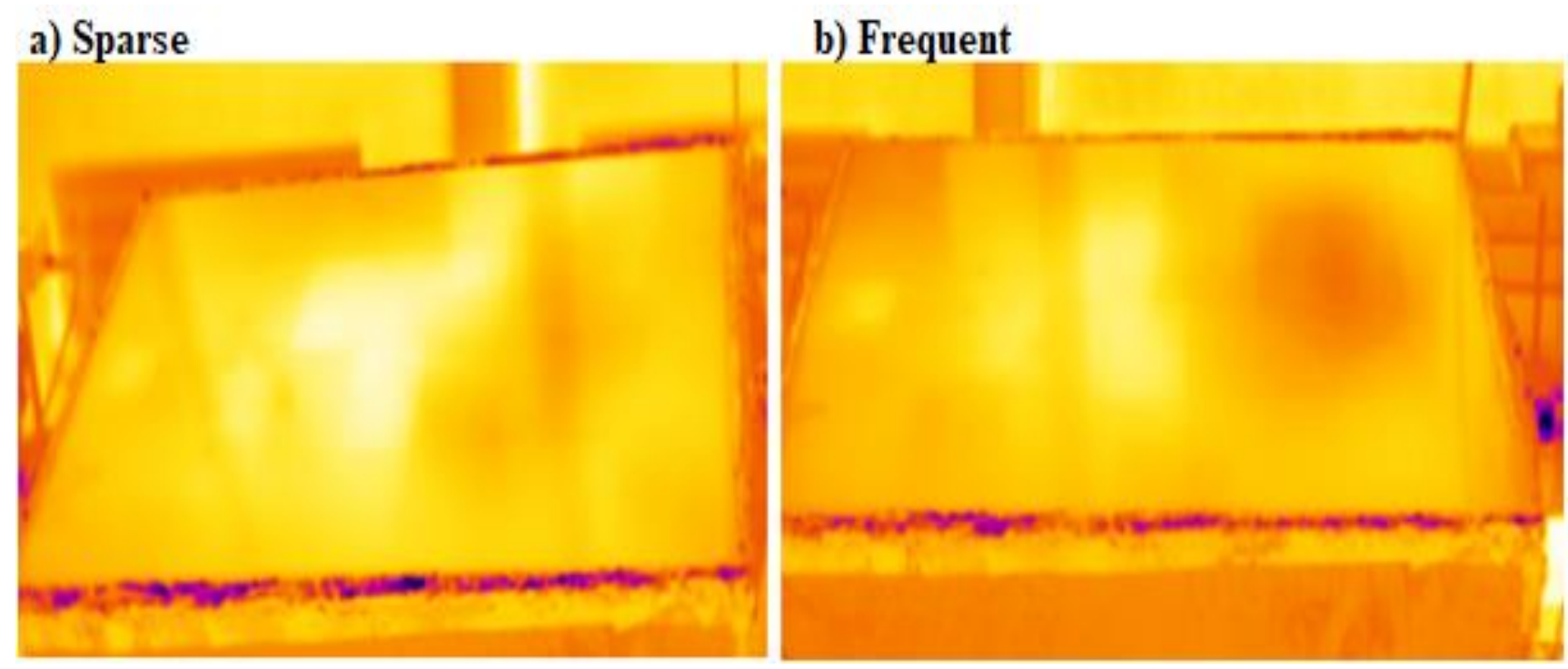

Figure 5. Thermal camera images of polycrystal panel surface. (a) Surface temperature for sparse configuration fins: $45-48^{\circ} \mathrm{C}$. b) Surface temperature for sparse configuration fins: $45-47^{\circ} \mathrm{C}$ ).

\section{ANSYS Fluent Analysis}

The temperature distributions in cooling duct for both sparse and frequent fin configurations of PVT system were examined with ANSYS Fluent for four different air velocities and images obtained were shown in Figure 6. Analyzes were performed for polycrystal panel. Figure 6 shows that a temperature gradient forms along each fin. While temperature values of fins are high at contact points to rear surface of panel, it is seen that it decreases gradually as it moves away from panel surface. This indicates that waste heat on panel surface is transferred to fins by conduction. Furthermore, temperature of fins at points of contact with rear surface of panel is about $320 \mathrm{~K}\left(47^{\circ} \mathrm{C}\right)$. Although there is a certain temperature differing among cell temperature and contact points of fins, the cell temperature reduced to the ideal operating temperature thanks to cooling process. The results of ANSYS Fluent analysis are highly compatible with images obtained via thermal camera. 
Effect of Using Fins on Cell Temperature at Air-Based PVT

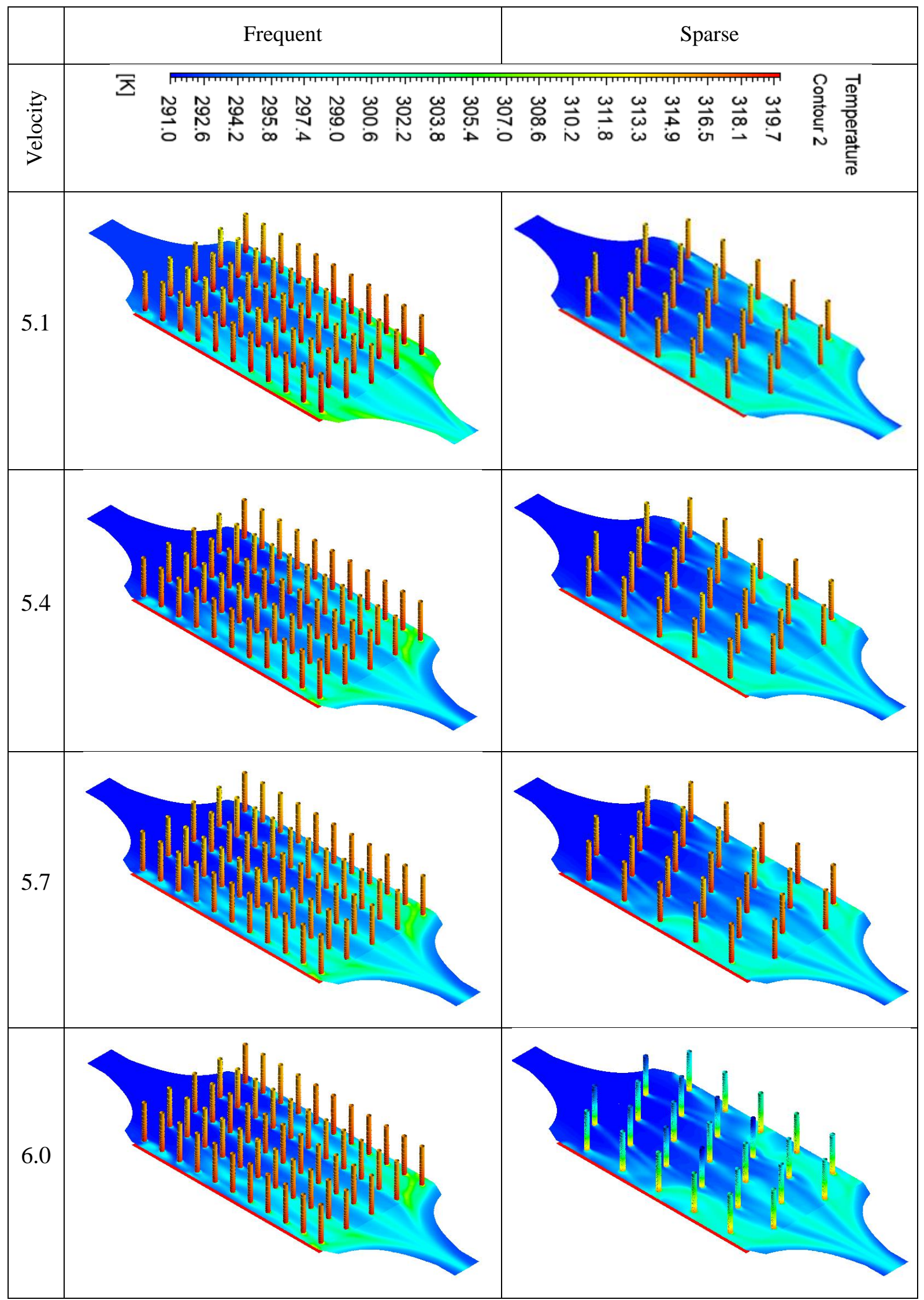

Figure 6. Temperature distributions for four different air velocity of both sparse and frequent fins configurations for polycrystal panel. 
In addition, velocity distributions in cooling duct were analyzed. Figures 7-8 shows velocity contour obtained from ANSYS Fluent for sparse and frequent configurations. As shown in Figures 7 8 , airspeed of fan is extremely low in areas close to fins. This occurs as a result of non-slip condition caused by both friction effect and viscous forces. In inlet and outlet regions of air duct and in regions between fins, it observed that airspeed of fan increased. In both configurations, the air velocity on both sides of the duct was extremely low. This situation shows that more careful attention should be paid to selection of fins location during cooling duct design. Fan airspeed of frequent fin configuration is relatively lower than fan airspeed of sparse fin configuration. This, because frequent configuration has a larger number of fins than sparse configuration, and friction and viscous effects caused by them. Laminar flow was observed in inlet-outlet regions of air duct and in regions between fins. Turbulent flow was observed in both right and left sides of region where airflow contacts fins.

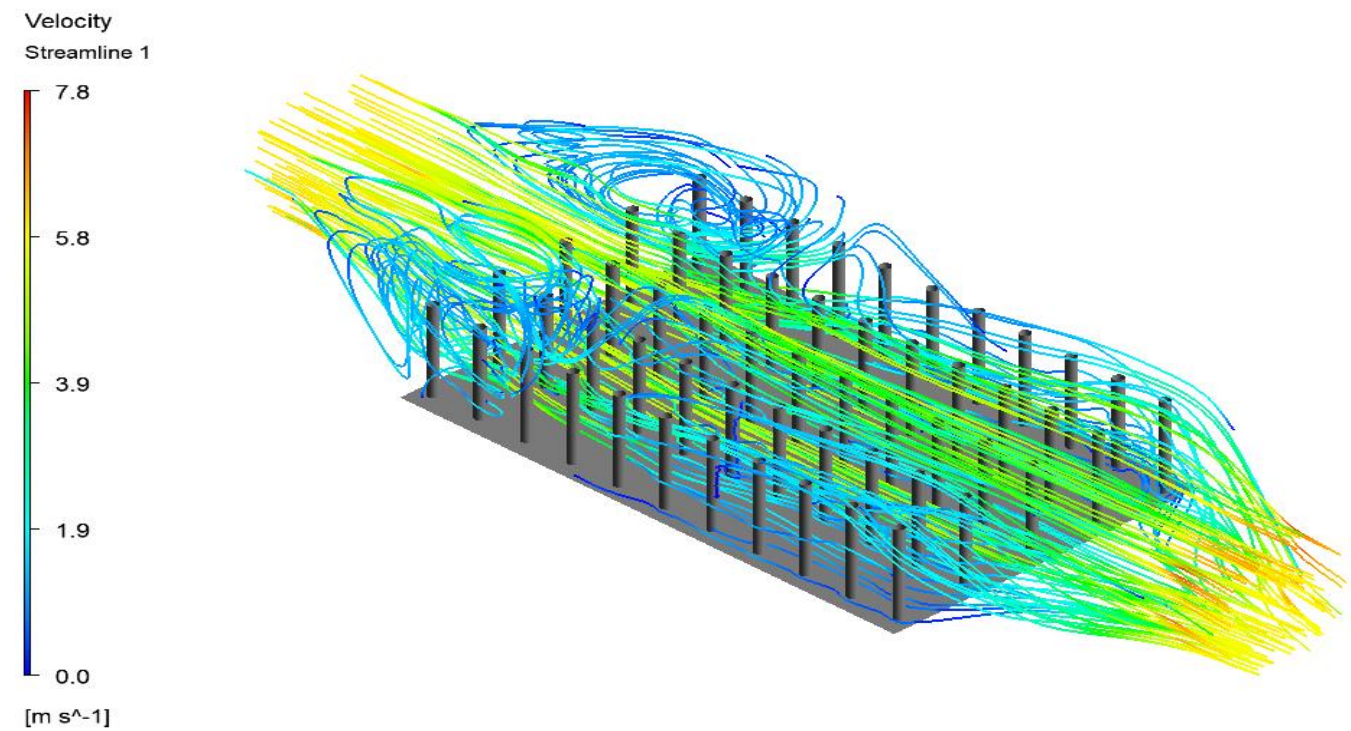

Figure 7. The velocity contour of frequent fins configuration
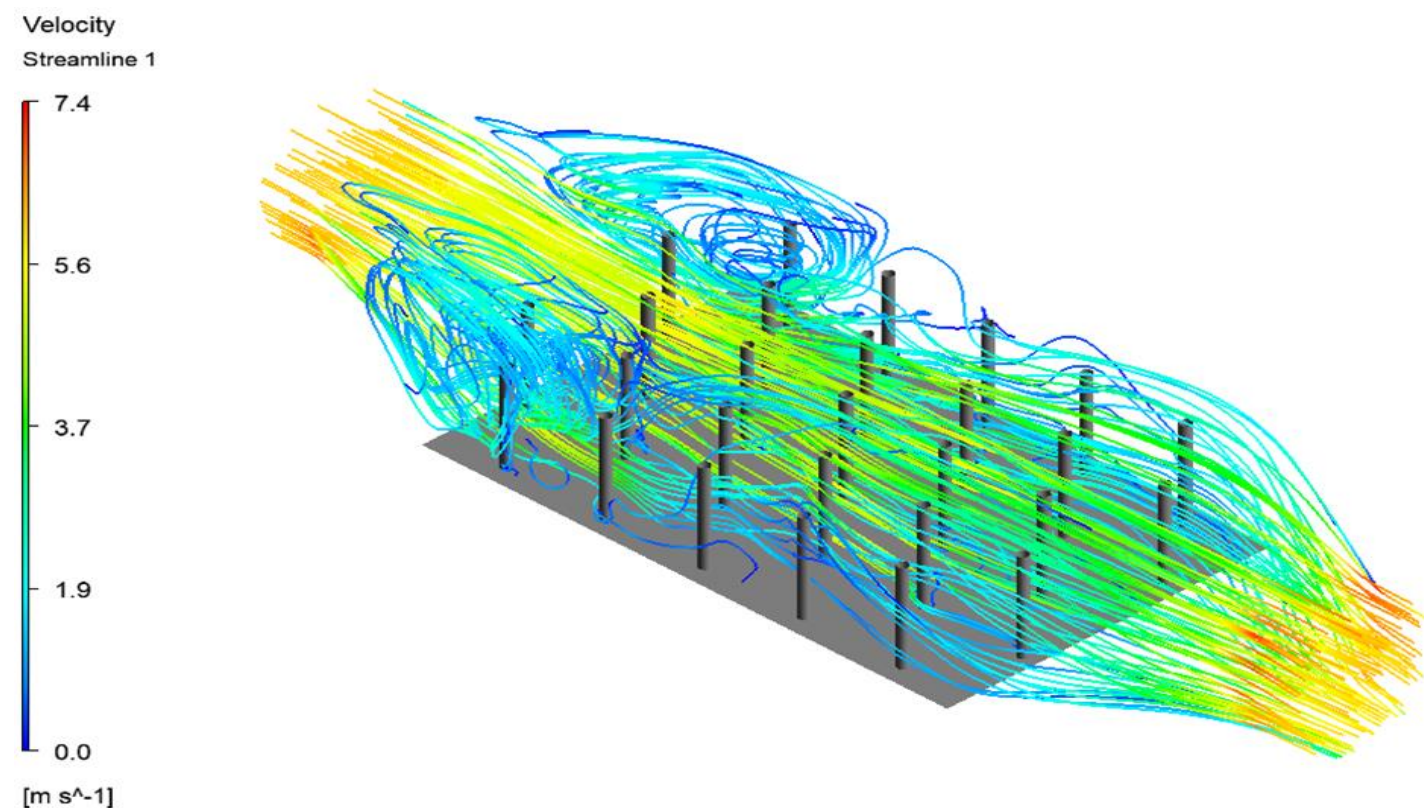

Figure 8. The velocity contour of frequent fins configuration 


\section{CONCLUSIONS}

In this study, effect of using fins on surface temperature of panel at air-based PVT system was investigated. Experiments were made for empty, sparse and frequent fins configurations. In addition, images of panel surface obtained by thermal camera were investigated and compared to images obtained by Fluent Ansys. Results are offered below.

- A temperature difference $(\Delta \mathrm{T})$ occurred between the input and output of the cooling channel. When the air velocity was increased from $5.1 \mathrm{~m} \mathrm{~s}^{-1}$ to $6 \mathrm{~m} \mathrm{~s}^{-1}$, in monocrystal panel, $\Delta \mathrm{T}$ value changed between $0.85-0.6{ }^{\circ} \mathrm{C}$ for the empty state; it changed between $2.2-1.85{ }^{\circ} \mathrm{C}$ for sparse fins condition; it changed between $3.35-3{ }^{\circ} \mathrm{C}$ for frequent fins. Similarly, in polycrystal panel, when the air velocity was increased from $5.1 \mathrm{~m} \mathrm{~s}^{-1}$ to $6 \mathrm{~m} \mathrm{~s}^{-1}, \Delta \mathrm{T}$ value changed between $0.75-0.65^{\circ} \mathrm{C}$ for the empty state; it changed between $2.15-1.85^{\circ} \mathrm{C}$ for sparse fins condition; it changed between $3.35-3{ }^{\circ} \mathrm{C}$ for frequent fins.

- Cell temperatures for empty, sparse and frequent fin configuration of both polycrystal and monocrystal panel decreased between $8-20{ }^{\circ} \mathrm{C}$. Thereby, it observed that the panel surface temperature for all configurations of both panels is extremely close to $47^{\circ} \mathrm{C}$, which is the ideal operating temperature.

- As a result of cooling process applied according to images obtained from thermal camera images, uniform temperature distribution on panel surface was observed especially for frequent and sparse fin configurations of polycrystal panels.

- Temperature contour images obtained via ANSYS Fluent were an agreement with experimental results and thermal camera images.

\section{ACKNOWLEDGEMENTS}

The authors represent their gratitude to the financial support provided by Atatürk University Scientific Research Project Unit under the BAP/2015-147 numbered project.

\section{Nomenclature}

\begin{tabular}{|c|c|c|c|}
\hline cap & capacity & $\mathrm{Ni}$ & nickel \\
\hline cond & conductivity & PCM & phase change material \\
\hline $\mathrm{Cu}$ & copper & PV & photovoltaic \\
\hline${ }^{\circ} \mathrm{C}$ & degrees Celsius & PVT & photovoltaic thermal \\
\hline $\mathrm{dm}$ & decimeter & $\mathrm{rpm}$ & revolutions per minute \\
\hline $\mathrm{I}$ & current $(\mathrm{A})$ & $\mathrm{s}$ & second \\
\hline $\mathrm{I}_{\max }$ & maximum current $(\mathrm{A})$ & $\mathrm{sc}$ & short circuit \\
\hline $\mathrm{I}_{\mathrm{sc}}$ & short circuit current (A) & Tol & tolerance \\
\hline $\mathrm{V}_{\mathrm{sc}}$ & short circuit voltage $(\mathrm{V})$ & $\mathrm{T}$ & temperature \\
\hline $\mathrm{V}$ & volt & Therm & thermal \\
\hline K & Kelvin & $\mathrm{V}$ & $\operatorname{volt}(\mathrm{V})$, velocity $\left(\mathrm{ms}^{-1}\right)$ \\
\hline Kcal & kilocalori & $\mathrm{W}$ & watt \\
\hline $\mathrm{kg}$ & kilogram & Greek letters & temperature difference $\left(\mathrm{K}\right.$ or $\left.{ }^{\circ} \mathrm{C}\right)$ \\
\hline $\mathrm{m}$ & meter, micro, maximum & $\Delta \mathrm{T}$ & micro ohm $\left(10^{-6} \mathrm{ohm}\right)$ \\
\hline $\mathrm{mm}$ & millimeter & $\mu \Omega$ & \\
\hline $\max$ & maximum & & \\
\hline
\end{tabular}




\section{Effect of Using Fins on Cell Temperature at Air-Based PVT}

\section{REFERENCES}

Al-Waeli AHA, Sopian K, Kazem HA, Chaichan MT, 2017. Photovoltaic/Thermal (PV/T) systems: Status and future prospects. Renewable and Sustainable Energy Reviews. 77: p. 109-130.

Bahaidarah HMS, Subhan, A, Gandhidasan P, Rehman S, 2013. Performance evaluation of a PV (photovoltaic) module by back surface water cooling for hot climatic conditions. Energy. 59: p. 445-453.

Bahaidarah HMS, Baloch AAB, Gandhidasan P, 2016. Uniform cooling of photovoltaic panels: A review. Renewable and Sustainable Energy Reviews. 57: p. 1520-1544.

Baloch AAB., Bahaidarah HMS., Gandhidasan P, Al-Sulaiman FA, 2015. Experimental and numerical performance analysis of a converging channel heat exchanger for PV cooling. Energy Conversion and Management. 103: p. 14-27.

Bayrak F, Hamdeh NA, Alnefaie KA, Öztop HF, 2017. A review on exergy analysis of solar electricity production. Renewable and Sustainable Energy Reviews, . 74: p. 755-770.

Bora B, Kumar R, Sastry OS, Prasad B, Mondal S, 2018. Energy rating estimation of PV module technologies for different climatic conditions. Solar Energy. 174: p. 901-911.

Ceylan, İ, Yilmaz S, İnanç Ö, Ergün A, Gürel AE, Acar B, 2019. Determination of the heat transfer coefficient of PV panels. Energy. 175: p. 978-985.

Chandel SS, Agarwal T, 2017. Review of cooling techniques using phase change materials for enhancing efficiency of photovoltaic power systems. Renewable \& Sustainable Energy Reviews. 73: p. 1342-1351.

Chauhan A, Tyagi V, Anand S, 2018. Futuristic approach for thermal management in solar PV/thermal systems with possible applications. Energy Conversion and Management. 163: p. 314-354.

Cuce E, Cuce PM, Bali T, 2013. An experimental analysis of illumination intensity and temperature dependency of photovoltaic cell parameters. Applied Energy,. 111: p. 374-382.

Dubey S, Tay AAO, 2013. Testing of two different types of photovoltaic-thermal (PVT) modules with heat flow pattern under tropical climatic conditions. Energy for Sustainable Development. 17(1): p. 1-12.

Dubey S, Tiwari GN, 2008. Thermal modeling of a combined system of photovoltaic thermal (PV/T) solar water heater. Solar Energy. 82(7): p. 602-612.

Fayaz H, Rahim NA, Hasanuzzaman M, 2019. A Rivai Numerical and outdoor real time experimental investigation of performance of PCM based PVT system. Solar Energy. 179: p. 135-150.

Gang P, Huide F, Tao Z, Jie J. 2011. A numerical and experimental study on a heat pipe PV/T system. Solar Energy. 85(5): p. 911-921.

Ghosh S, Yadav, VK, Mukherjee V, 2019. Impact of environmental factors on photovoltaic performance and their mitigation strategies-A holistic review. Renewable Energy Focus. 28: p. 153-172.

Gökmen N, Hu W, Hou P, Chen Z, Sera D, Spataru S, 2016. Investigation of wind speed cooling effect on PV panels in windy locations. Renewable Energy. 90: p. 283-290.

Kaiser AS, Zamora B, Mazón R, García JR, Vera F, 2014. Experimental study of cooling BIPV modules by forced convection in the air channel. Applied Energy. 135: p. 88-97.

Kaldellis JK, M Kapsali, Kavadias KA, 2014. Temperature and wind speed impact on the efficiency of PV installations. Experience obtained from outdoor measurements in Greece. Renewable Energy. 66: p. 612-624.

Kalogirou SA, 2001. Use of TRNSYS for modelling and simulation of a hybrid pv-thermal solar system for Cyprus. Renewable Energy. 23(2): p. 247-260.

Kazemian A, Hosseinzadeh M, Sardarabadi M, 2018. Effect of glass cover and working fluid on the performance of photovoltaic thermal (PVT) system: An experimental study. Solar Energy. 173: p. 1002-1010.

Kumar, R. Rosen MA, 2011a. A critical review of photovoltaic-thermal solar collectors for air heating. Applied Energy. 88(11): p. 3603-3614.

Kumar R, Rosen MA, 2011b. Performance evaluation of a double pass PV/T solar air heater with and without fins. Applied Thermal Engineering. 31(8): p. 1402-1410.

Lamnatou C, Chemisana D, 2017. Photovoltaic/thermal (PVT) systems: A review with emphasis on environmental issues. Renewable Energy. 105: p. 270-287.

Omer KA, Zala AM, 2018. Experimental investigation of PV/thermal collector with theoretical analysis. Renewable Energy Focus. 27: p. 67-77.

Özakin AN, Kaya F, 2019. Effect on the exergy of the PVT system of fins added to an air-cooled channel: A study on temperature and air velocity with ANSYS Fluent. Solar Energy. 184: p. 561-569.

Özakin AN, Kaya F, 2020. Experimental thermodynamic analysis of air-based PVT system using fins in different materials: Optimization of control parameters by Taguchi method and ANOVA. Solar Energy. 197: p. 199-211.

Saidur R, Jazi GB, Mekhlif S, Jameel M, 2012.Exergy analysis of solar energy applications. Renewable and Sustainable Energy Reviews. 16(1): p. 350-356.

Shukla A, Kanta K, Sharmaa A, Biwole PH, 2017. Cooling methodologies of photovoltaic module for enhancing electrical efficiency: A review. Solar Energy Materials and Solar Cells. 160: p. 275-286. 
Tonui JK, Tripanagnostopoulos Y, 2008. Performance improvement of PV/T solar collectors with natural air flow operation. Solar Energy. 82(1): p. 1-12.

Ustun TS, Nakamura Y, Hashimoto J, Otani K, 2019.Performance analysis of PV panels based on different technologies after two years of outdoor exposure in Fukushima, Japan. Renewable Energy. 136: p. 159-178.

Venkateswari R, Sreejith S, 2019. Factors influencing the efficiency of photovoltaic system. Renewable and Sustainable Energy Reviews. 101: p. 376-394.

Wu SY, Wang T, Xiao L, Shen ZG, 2019. Effect of cooling channel position on heat transfer characteristics and thermoelectric performance of air-cooled PV/T system. Solar Energy. 180: p. 489-500.

Yang T, Athienitis AK, 2014. A study of design options for a building integrated photovoltaic/thermal (BIPV/T) system with glazed air collector and multiple inlets. Solar Energy. 104: p. 82-92.

Yang T, Athienitis AK, 2015. Experimental investigation of a two-inlet air-based building integrated photovoltaic/thermal (BIPV/T) system. Applied Energy. 159: p. 70-79. 